\title{
Beyond Doom And Gloom in Petroaesthetics: FACing OIL, MAKing Energy MATter
}

\author{
BART H. WELLING
}

"There is an important sense in which the only thing that doesn't seem to matter anymore is matter."

- Karen Barad, Meeting the Universe Halfway

\section{Introduction}

Among the many factors holding back progress on a worldwide transition to alternative energy, some of the thorniest problems have to do with how we see and represent - and avoid seeing and representing — petroleum, coal, and natural gas. To build on Karen Barad's point, hydrocarbons ${ }^{1}$ will not matter as they should (i.e., be considered as important as they actually are) until we find new ways of viewing these substances, and the staggering human and ecological costs involved in extracting, processing, and burning them, as matter. Hydrocarbons and the "super wicked" 2 externalities of petroculture are hard to face for many reasons, not least of all because the fossil fuels industry works very hard to hide them behind the abstraction known as Energy. ${ }^{3}$ From

\footnotetext{
${ }^{1}$ I try to use "hydrocarbons" as much as possible, rather than "fossil fuels," because the latter term presupposes that oil, coal, and natural gas are somehow destined to be used and imagined only in the ways in which we currently use and imagine them. "Hydrocarbons" is not only accurate and concise, but it gently defamiliarizes these substances in a way that sidesteps polarized and entrenched ways of talking about them, thereby opening them up to being invested with new meanings.

${ }^{2}$ On global warming as a "super wicked" problem, see Kelly Levin, Benjamin Cashore, Steven Bernstein, and Graeme Auld. "Overcoming the Tragedy of Super Wicked Problems:

Constraining Our Future Selves to Ameliorate Global Climate Change," Policy Sciences 45, no. 2 (2012): 123-52.

${ }^{3}$ I capitalize the word partly to signal the quasi-supernatural character of this view of things and partly to distinguish the industry's euphemistic handling of it from definitions employed by scientists, who are keenly aware of how much damage the euphemism has done.
} 
the industry's perspective, the ideal consumer is one who never sees or thinks about crude oil or Cancer Alley, ${ }^{4}$ coal mines or climate disruption, a consumer who continues to pay for Energy and vote for politicians more interested in their short-term job security than in the long-term future of life on Earth.

Ironically, image-makers opposed to the petrocultural status quo may have helped perpetuate it by favouring apocalyptic and Gothic "petroaesthetics": an aesthetic of "doom" on the one hand, and one of "gloom" on the other. ${ }^{5}$ These ways of visualizing hydrocarbons take them seriously as matter in Barad's sense, but tend to overlook their formidable life-giving, jobcreating, and comfort-providing powers. Moreover, doomy and gloomy approaches obscure viewers' ethical relationships with oil, coal, and natural gas, along with the human and biological communities harmed by petroculture, by focusing on spectacular or profoundly miserable calamities, such as burning gushers and oil spills, in which hydrocarbons are framed as unnatural monstrosities rather than naturally occurring substances that human cultures have known and used on a small scale for thousands of years (albeit ones that industrial states have abused on an enormous scale for the last few centuries). "Petro-apocalyptic" and "petro-Gothic" representations of the 1969 Santa Barbara, California oil spill and the Exxon Valdez spill twenty years later have been widely credited with sparking the public outrage that first launched and later revitalized the modern American environmental movement. ${ }^{6}$ However, on the fortieth anniversary of the first Earth Day, almost exactly twenty years after the Valdez ran aground, as millions of barrels of crude oil were beginning to spew into the Gulf of Mexico from a shattered wellhead nearly a mile beneath the ocean surface, it was clear that, while doom-and-gloom representational strategies could still be used to demonize corporations such as BP, they were

${ }^{4}$ This is the nickname of a stretch of the Mississippi River in Louisiana that is home to over 150 petrochemical plants, oil refineries, and other hydrocarbon processing facilities. Also known as the "Chemical Corridor," the region became known as "Cancer Alley" thanks to the well-above-average number of deaths and illnesses associated with the massive amounts of pollutants these facilities release into the local environment.

5 I borrow the term "petroaesthetics" from Catherine Zuromskis (2014), who applies it to photographs of gas stations, oil fields, and other petrocultural sites, but does not talk about representations of petroleum as a substance.

${ }^{6}$ On the huge cultural and political impacts of media images of the Santa Barbara spill see, for example, Kathryn Morse, "There Will Be Birds: Images of Oil Disasters in the Nineteenth and Twentieth Centuries," The Journal of American History 99, no. 1 (2012): 129-32. On the "tremendous expansion in citizen participation" that resulted from the Exxon Valdez disaster, caused in large part by "media hyper-vigilance" regarding oil spills, see Rick S. Kurtz, "Coastal Oil Pollution: Spills, Crisis, and Policy Change," Review of Policy Research 21, no. 2 (2004):

210-11. 
doing little to awaken consumers to their own deep enmeshment in petroculture, or to help generate the political will that will be necessary if we are to leave the Age of Hydrocarbons behind. More recent events would seem to have confirmed that fear and loathing of hydrocarbons have not worked as imaginative "fuel source[s]" in overcoming the idea of Energy and powering renewable energy transitions. ${ }^{7}$ The U.S. White House is currently occupied by a global warming skeptic who never tires of saying how much he loves "beautiful, clean coal," and, even if market forces have exposed Trump's coal rhetoric as nothing more than a way of pandering to the struggling citizens of coal-rich but cash-poor states such as West Virginia, the rate of global consumption of petroleum and natural gas continues to climb. ${ }^{8}$

The study of petroaesthetics so far has mostly focused on limitations in contemporary ways of representing oil depletion, global warming, and related problems. In numerous publications, Imre Szeman has anatomized the failure of thinkers across the political spectrum to imagine viable futures after petrocapitalism. Fortunately, more productive ways of visualizing hydrocarbons than the discourses critiqued by Szeman do exist_-ways of representing them that resist virtualizing them as Energy or merely thematizing them (i.e., treating them as objects of representation that have no impact on the means of representation) and, instead, grapple with their strange materialities and agencies, their cultural centrality as artistic and other kinds of media in their own right. This essay begins with an overview of some of the many normally

\footnotetext{
${ }^{7}$ Of course there are many reasons for hydrocarbons' continuing dominance of the world's energy systems despite the mountains of evidence that industrial societies should have begun wholesale transitions away from them decades ago. Perhaps I am overestimating the cultural power of petro-representations, expecting much more from them than they can be expected to do (and, conversely, blaming them for problems for which they are not responsible). On the other hand, the massive public responses to the Santa Barbara and Exxon Valdez spillsresponses triggered not by the simple fact that the spills had happened but by particular media representations of them - highlight the need for further analysis of the relationships between representations of hydrocarbons and modern humanity's ways of perceiving them and living with them. On the cultural "fuel source[s]" that we need to transition to an alternative energy society, see Bill McKibben, "Introduction," in American Earth: Environmental Writing Since Thoreau, ed. Bill McKibben (New York: Library of America, 2008), xxvi-xxvii.

${ }^{8}$ Donald Trump has referred to coal on numerous occasions as "clean" and "beautiful"; most significantly, in his first State of the Union address before Congress, he claimed that "We have ended the war on American energy. And we have ended the war on beautiful, clean coal." (The "beautiful" was evidently ad-libbed.) See "President Trump's State of the Union Address: FactCheck and Analysis," Politico, January 30, 2018, https://www.politico.com/interactives/2018/trump-state-of-the-union-2018-transcript-analysis/. On oil and gas production rates, see International Energy Agency, Key World Energy Statistics 2017 (Paris: International Energy Agency, 2017), 12-15.
} 
unexamined ways in which hydrocarbons mediate modern humans' and nonhumans' experiences of the world. Then, after exploring how the fossil fuels industry obfuscates these mediations by means of the idea of Energy, and why petro-apocalyptic and petro-Gothic ways of seeing oil in particular are evidently failing to contribute much to a civilization-wide transition to renewables, I examine the work of artists who are experimenting with new petroaesthetics, starting with aerial photographer Louis Helbig. The essay concludes with a discussion of works by two artists, Warren Cariou and Kathleen Thum, who are challenging traditional petroaesthetics by employing petroleum itself as an artistic medium. I approach Helbig, Cariou, and Thum's projects, along with petroleum, the hydrocarbons industry, and petroculture in general, from a position informed by the work of such new materialist thinkers as Jane Bennett and by W. J. T. Mitchell's redefinition of media theory as "medium theory": a way of analyzing media that does not treat them as "an 'object' for scrutiny by the master discourses of theory," but that "acknowledge[s] its [own] middling, muddling location in the midst of media"; this theory is an "immanent vernacular, closely tied to practice while reflecting on it from within." I argue that by attending to the weird blurrings of nature and culture, art and industry in petroleum-based and otherwise unconventional representations of petroculture, we can better understand our "middling, muddling location" within oil, and can start not just caring about hydrocarbons but caring for these normally abject substances in a way that might help us want to keep them in the ground.

\section{Hydrocarbons as Media}

From a petrocritical standpoint, it makes perfect sense to think not just about how petroleum and the oil industry are represented in the media, but about how they constitute media in their own right. A review of some of the Oxford English Dictionary's definitions of "medium" shows how fruitful this way of thinking about oil (and other hydrocarbons) can be. As unoriginal or unsophisticated as a dictionary-based approach may sound, I actually find it revelatory as a way of uncovering how hydrocarbons intervene in essentially every aspect of modern life, for good as well as bad, and how common-sense, supposedly non-debatable understandings of media such as those expressed in the OED entries tend to overlook and conceal these essential petro-mediations.

First, petroleum can be characterized as a "medium of exchange"-i.e., "anything commonly agreed as a token of value and used in transactions in a

\footnotetext{
${ }^{9}$ W. J. T. Mitchell, What Do Pictures Want?: The Lives and Loves of Images (Chicago: University of Chicago Press, 2005), 221.
} 
trading system; esp. (also medium of circulation, circulating medium) freely circulating units of money, as banknotes, coins, which fulfill this role; currency..." Obviously we don't use oil as money in the same way that we use a dollar bill (imagine the mess!), but Andrew Pendakis correctly notes that petroleum is "preferred currency, an extremely common store of monetary value" and a "peculiar intensification of money" in terms of its impacts on flows of capital and, indeed, on the "body of all existing objects in the capitalist life-world." 10 The nickname "black gold" hints at oil's tremendous fungibility and centrality to the modern global economy. Just as the value of paper money in many countries was formerly based on the size of their gold reserves, a nation's wealth is currently tied in myriad ways to its access to large, cheap oil supplies, since petroleum powers the vast majority of transactions involving the movement of people and goods. What's more, modern money's rather frightening ability to effectively transform itself into almost every conceivable good and service is deeply entangled with the unique and volatile chemical properties of petroleum and other hydrocarbons, which can morph into a seemingly infinite array of other commodities and finished products that bear no resemblance to their original feedstocks. For these reasons it is fair to call oil the "commodity of commodities."

In geopolitics, oil's status as an irreplaceable global medium of exchange has periodically lent to its use as another kind of medium: "An intermediate agency, instrument, or channel; a means; esp. a means or channel of communication or expression." Petroleum was used as a material-discursive "means... of communication" during the 1973 oil crisis, for instance, when OPEC's majority-Arab member states cut off oil supplies to the U.S., Canada, and other countries as a way of expressing their outrage and punishing those who supported Israel during the Arab-Israeli War.

Artists have used hydrocarbons as media of expression for more benign purposes than those of politicians. As the OED notes, "medium" is defined in the art world as "Any of the varieties of painting or drawing as determined by the material or technique used. Hence more widely: any raw material or mode of expression used in an artistic or creative activity." To extend an observation made by Ross Barrett and Daniel Worden, petroleum and other hydrocarbons are important feedstocks in the making of various inks, pens, cameras, film stocks, acrylic paints, paintbrushes, and polymer clays, but they also power

${ }^{10}$ Andrew Pendakis, "Being and Oil: Or, How to Run a Pipeline through Heidegger," in Petrocultures: Oil, Politics, Culture, edited by Sheena Wilson, Adam Carlson, and Imre Szeman (Montreal, QC: McGill-Queens University Press, 2017), 385. 
vehicles and equipment associated with many different creative activities. ${ }^{11}$ By this definition, for example, petroleum-based fuel has as good a claim as $35 \mathrm{~mm}$ film to be labeled the medium of an aerial shot captured from a helicopter.

Stephanie LeMenager is right: "Oil itself is a medium that fundamentally supports all modern media forms concerned with what counts as culture-from film to recorded music, novels, magazines, photographs, sports, and the wikis, blogs, and videography of the Internet."12 In addition to plastic film stock and fossil fuels used to power creative activities, think of vinyl LPs, compact discs, DVDs, and the many varieties of plastic audiotape and computer storage media synthesized from hydrocarbons; the OED points out that "medium" can refer to "Any physical material (as tape, disk, paper, etc.) used for recording or reproducing data, images, or sound." And, of course, the information stored on these media cannot be accessed without devices that are themselves made of and with hydrocarbons and, typically, powered by fossil energy. Just as oil is the commodity of commodities, it is the medium of media.

And just as we see pretty much everything these days through hydrocarbon-derived and petrocultural artistic and technological lenses, all of our perceptions of the world - not just visual but auditory, olfactory, gustatory, and haptic - are mediated to some degree by various forms of hydrocarbon pollution. "Medium," according to the OED, can refer to "An intervening substance...through which impressions are conveyed to the senses; any substance considered with regard to its properties as a vehicle of light or sound." In the modern petrocultural world, where Earth's atmosphere has been reengineered (in Bill McKibben's words) into an "open sewer"13 for the dumping of smog, waste carbon dioxide, and other greenhouse gases and pollutants, air has been transformed into a medium for the mostly uncontrolled transmission of hydrocarbon-based toxins, smells, noises, and vision-altering particles. For example, the United States Environmental Protection Agency notes that emissions from cars, coal-fired power plants, and other sources have reduced the average range of vision in national parks in eastern states from 90

\footnotetext{
${ }^{11}$ Ross Barrett and Daniel Worden, "Introduction," in Oil Culture, eds. Barrett and Worden (Minneapolis, MN: University of Minnesota Press, 2014), xix.

${ }^{12}$ Stephanie LeMenager, Living Oil: Petroleum Culture in the American Century (New York: Oxford University Press, 2014), 6.

${ }^{13}$ Bill McKibben, "A Revolution in Our Atmosphere, From Burning Too Many Fossil Fuels" HuffPost, February 2, 2011, https://www.huffingtonpost.com/bill-mckibben/a-revolution-inour-atmos_b_817860.html.
} 
miles to between 15 and 25 miles. ${ }^{14}$ The millions of tourists who drive every year to the most heavily visited of all U.S. national parks, Great Smoky Mountains, unwittingly help produce the smoky mountain aesthetic encounters they seek as they spew exhaust out of the tailpipes of their Harley-Davidsons and Toyota Siennas. ${ }^{15}$ City soundscapes everywhere are dominated by the hum, clatter, groan, and roar of internal combustion engines. Even in a remote wilderness area such as Canyonlands National Park in Utah, noise pollution from jet airplanes and other aircraft interrupts the song of birds and the sound of the wind every few minutes. ${ }^{16}$ Of course, it would be impossible to list all of the ways in which carbon emissions from fossil fuels have come to mediate not just humanity's experiences of the world but the day-to-day lives and relationships of virtually all species on the planet.

In light of the ubiquity of hydrocarbons' impacts on the biosphere and these impacts' provenance in the modern world's deep dependence on fossil fuels, it makes sense to describe petroleum as a medium comparable to the kind that bacteria inhabit in laboratories: "A pervading or enveloping substance; the substance in which an organism lives; esp. one in which microorganisms, cells, etc., are cultured. In extended use: one's environment, conditions of life, or usual social setting." This OED definition corresponds with the term "petroculture," which neatly summarizes the staggeringly vast and complex array of hydrocarbon-mediated infrastructures and relationships that constitute human life in the developed world. We may not exactly swim around in petroleum like Paramecia in a Petri dish, but any extraterrestrial scientists observing us would be right to conclude that most of us in the West are just as dependent for our survival on hydrocarbons and hydrocarbon-based technologies as laboratory-bound microorganisms are on their growth media. ${ }^{17}$ Like the climate that they are dramatically transforming, hydrocarbons set the conditions of possibility not just for human survival but for art, politics, and every other branch of culture. "Oil is not just energy," Imre Szeman reminds us;

\footnotetext{
${ }^{14}$ United States Environmental Protection Agency, "Basic Information about Visibility," EPA.gov. Last modified April 25, 2017, https://www.epa.gov/visibility/basic-informationabout-visibility.

${ }^{15}$ As much as I would like to indulge in some righteously indignant Harley-bashing here, I must confess that my family owns a Sienna and, yes, we have driven it to the Smokies.

${ }^{16}$ See Gordon Hempton and John Grossman, One Square Inch of Silence: One Man's Quest to Preserve Quiet (New York: Free Press, 2009), 121-56.

17 This observation was inspired by Allan Stoekl's point that "an extraterrestrial observing earth could be forgiven for thinking that cars are the dominant species, and humans are bred simply to serve them." "Unconventional Oil and the Gift of the Undulating Peak," Imaginations 3, no. 2 (2012): 41.
} 
it is something without which recent history "would have been utterly different," and it is “ontology, the structuring 'Real' of our contemporary sociopolitical imaginary[.]"18

Hydrocarbons even have something in common with the type of medium defined in the OED as "A person believed to be in contact with the spirits of the dead and to communicate between the living and the dead." After all, crude oil, coal, and natural gas consist of the geologically transformed remains of long-dead algae, plankton, giant tree ferns, and other life-forms. In a sense, hydrocarbons in their present forms communicate between their past selves and us. By the same token, when burned, they communicate between us and future inhabitants of the planet. The ghostly or "undead"19 atmospheric traces of burned hydrocarbons will mediate between the past few generations of humans and countless future generations of humans and nonhuman beings as Earthlings of every taxonomic kingdom and species struggle to adapt to the new ecological realities ushered in by global petroculture. Along with such phenomena as nuclear waste and the mass extinction of nonhuman species, hydrocarbon emissions will serve as one of the main media through which contemporary humanity will haunt the future, communicating our profound disregard for the lives of those to whom we bequeath a badly wounded Earth.

One fundamental problem is that most people in hydrocarbon-dependent countries only seem to think of petroleum (when they think about it at all) as a medium in the first sense, as a "medium of exchange." From this vantage point, oil is a rarely- or never-seen substance that we do not so much burn as trade for speed, comfort, food, prestige, vacation fun, and much more. Using oil in this way shrinks our bank accounts, but it apparently does not fundamentally transform us as human beings or change our way of seeing things; nor does it seem to have any more impact on the world around us than does the act of swiping a credit card at the pump. That is something else we share with Paramecia in the laboratory: a profound obliviousness regarding the media that keep us alive, ranging from our badly abused atmosphere to endangered oxygen-producing rain forests and oceans to the global food industry, which, if the flow of hydrocarbons were to stop tomorrow, would collapse swiftly and irrevocably, leading to mass starvation in countries that currently enjoy a hyperabundance of food.

\footnotetext{
${ }^{18}$ Imre Szeman, "The Cultural Politics of Oil: On Lessons of Darkness and Black Sea Files," Polygraph, no. 22 (2010): 34.

${ }^{19}$ Oxana Timofeeva writes that fossil fuels constitute a "highly exploited, undead, non-human material agency." See Timofeeva, “Afterword," Mediations 31, no. 2 (2018): 146.
} 


\section{The Myth of Energy}

Obliviousness to the world-destroying effects of oil dependence is something that the oil industry has worked almost as hard to produce as petroleum. The industry has spent countless billions of dollars fostering public ignorance of the externalities of oil not only through upbeat television commercials, hefty bribes and/or legal campaign contributions to politicians, and donations to organizations that promote climate change skepticism, but through infrastructure design (e.g., by making their facilities nondescript and in the peripheries as much as possible) and through actions such as BP's dumping of almost two million gallons of the dispersant with the Orwellian name of Corexit in the Gulf of Mexico in 2010 with the goal not of "correcting" the spill but, evidently, of getting as much spilled crude as possible to sink out of sight. ${ }^{20}$

One of the most effective strategies the fossil fuels industry employs to obfuscate the realities of hydrocarbons-as-media involves substituting the euphemism Energy for petroleum, coal, and natural gas in corporation names (e.g., Peabody Energy, formerly known as Peabody Coal), in slogans (e.g., Chevron's ongoing "Human Energy" campaign), and in advertisements such as ExxonMobil's "Energy Lives Here Anthem" (2013). In that commercial, fossil fuels are not visualized as gloppy liquids, poisonous gases, stained beaches, exploding mines, and exploited workers. Rather, Energy is represented by shimmering, gently pulsing waves of iridescent light that closely resemble the standard computer-generated Hollywood signifiers for magical powers, extraterrestrial forces, and human technologies in the distant future. "Energy Lives Here Anthem" is a dramatic example of what I call the myth of Energy. ${ }^{21}$ This is a complex of narratives and images that counts as a myth in three senses of the word: it explains and rationalizes the status quo; it both depends on and nurtures a quasi-religious belief in an omnipresent and mighty — but benevolent - higher power; and, as an account of the way reality works, it is mostly false. Just as the petroleum refining process cracks crude oil into its different components and removes water and traces of the liquid's origin sites (framed as impurities) from the hydrocarbon stew, the myth of Energy rhetorically transforms the ecologically, politically, and morally filthy substances we extract from subterranean deposits and burn in gargantuan

\footnotetext{
${ }^{20}$ See LeMenager, 125.

${ }^{21}$ For more on the myth of Energy, see Bart Welling, "Petronarratology: A Bioregional Approach to Oil Stories," English Studies 99, no. 4 (2018): 446-47.
} 
quantities into a seemingly magical force that is immaterial, perfectly clean, apolitical, virtually omnipotent but harmless, and inexhaustible. ${ }^{22}$

Mel Evans exposes a similar type of rhetorical refinery work in her book Artwash: Big Oil and the Arts, which focuses on how petroleum corporations both distract attention from their heinous ecological and human rights records and "take on a thoughtful, refined, cultured persona...for an audience of special publics" made up of "opinion-formers occupying influential positions in the media and politics." 23 The corporations do this by sponsoring art museums, ballets, theatres, public broadcasting networks, symphonies, operas, and music festivals, among other things.

But the oil industry is just as interested in reaching the general public as in playing the role of a good corporate citizen for an audience of "special publics." In 2017, the industry-funded American Petroleum Institute spent around $\$ 5$ million $^{24}$ for thirty seconds of airtime during the Super Bowl (on top of production costs and associated web design expenses) to run an advertisement called "Oil: Power Past Impossible." After flashing the words "THIS AIN'T YOUR DADDY'S OIL," the ad continues with quick-cut footage of a graffiti artist spray-painting a day-glo mural, cans being filled with paint in a factory, and an artist running a brush through yellow and green paint, accompanied by a large purple caption stating "OIL GUSHES ART." A visit to the API's Power Past Impossible website shows that the caption is referring not

${ }^{22}$ Brent Ryan Bellamy and Jeff Diamanti discuss something similar to the myth of Energy in their account of the nineteenth-century development of the "doctrine of energy," a set of ideas based on the first law of thermodynamics (which states that, while energy "can be transformed from one form to another," it "can be neither created nor destroyed"). Following Thomas S. Kuhn, Bellamy and Diamanti note that this doctrine was profoundly indebted to scientists' engagements with the new steam engines of the Industrial Revolution. I agree with much of Bellamy and Diamanti's "critique of energy," in particular their insistence on the necessity of historicizing a seemingly immutable law of nature that appears to offer industrial capitalism "metaphysical immunity from economic and ecological catastrophe." However, in light of industrial capitalism's thorough co-optation of the word "energy," I believe that Bellamy and Diamanti, like other practitioners of the energy humanities, could devote more attention to the problematic rhetorical (and thus political) dimensions of the term itself. See Brent Ryan Bellamy and Jeff Diamanti, "Phantasmagorias of Energy: Toward a Critical Theory of Energy and Economy," Mediations 31, no. 2 (2018): 1-16.

${ }^{23}$ Mel Evans, Artwash: Big Oil and the Arts (London: Pluto Press, 2015), 13.

${ }^{24}$ According to Bradley Johnson, the average cost for thirty seconds of Super Bowl airtime in 2017 was \$5.13 million in 2018 inflation-adjusted U.S. dollars. See "Big Game Punting: Super Bowl Scores \$5.4 Billion in Ad Spending Over 52 Years," AdAge, January 11, 2018, http://adage.com/article/special-report-super-bowl/super-bowl-ad-spending-history-charts-52years $/ 311881 /$. 
to oil industry sponsorship of the arts but to the fact that many artistic media and tools are synthesized from petroleum. However, the commercial conveniently fails to provide information about how oil is extracted and processed to make artists' materials. Its refusal to consider the many human and ecological mediations involved in the process is expressed by way of footage that never shows so much as an oil rig or a pipeline, and through the "OIL GUSHES ART" caption's shift of agency from corporations and artists to petroleum itself. The commercial clearly qualifies as an example of artwashing, as well as a new iteration of the myth of Energy. What starts out as a potentially instructive dramatization of oil as an artistic medium quickly morphs into a willfully naïve celebration of the good old (albeit technologically advanced) "American way of life," a way of life predicated for most of the last century on public ignorance of the petro-mediations mentioned above. Fittingly, "Oil:

Power Past Impossible" ends with shots of a rocket launch and a space capsule heading out into the cosmos (accompanied by the caption "OIL EXPLORES SPACE"). To paraphrase Timothy Morton, this final sequence vividly illustrates petroleum's power to literally and conceptually help modern humans try to "achieve escape velocity from our physical and biological being"; at the same time, it studiously ignores the ironic truth that this "very attempt... has resulted in [our] being stuck to Earth," by way of oil spills and global warming in particular. ${ }^{25}$

\section{The Petro-Apocalyptic and the Petro-Gothic}

If the problem with artwashing and corporate self-representations is that they hide the ecological and human costs of extracting and using oil, then one might assume that an excellent way to promote a civilization-wide transition to alternative energy sources would involve saturating the mediascape with hardhitting depictions of these costs. Unfortunately, as successful as they have been in directing public outrage against corporations such as Exxon and BP, attempts by image-makers to render visible oil's impacts on human cultures and the biosphere have often failed to instill in viewers an understanding of petroleum as a complex and contradictory medium in the senses described above: a substance that we depend on for our survival, a life-destroying industry that we keep alive through this dependence, and a culture that shapes how we see (and smell, taste, touch, and hear) virtually everything. Indeed, many visualizations of oil traffic in imagery that distances viewers both literally and morally from

${ }^{25}$ Timothy Morton, Hyperobjects: Philosophy and Ecology after the End of the World (Minneapolis: University of Minnesota Press, 2013), 180. 
the consequences of their petrocultural lives, further externalizing these externalities instead of bringing them home - that is, instead of exposing petroculture as a network of relationships in which all citizens take part, and which they can thus help transform.

One type of imagery, which we could call the "petro-apocalyptic," carries out this distancing work by focusing on spectacles of fiery destruction on a sublime scale, as in the many helicopter shots of burning Kuwaiti oil wells featured in Werner Herzog's post-Gulf War documentary Lektionen in Finsternis [Lessons of Darkness] (1992). Accompanied by the soaring music of Wagner and other classical composers, and (at one point) by Herzog reading passages about the end of the world from the Christian Urtext of apocalyptic discourse, the book of Revelation (e.g., "And he opened the bottomless pit; and there arose a smoke out of the pit, as the smoke of a great furnace; and the sun and the air were darkened by reason of the smoke..."), these shots introduce viewers to a horizon-wide hellscape of raging fire-gushers spewing black clouds of smoke into the dirty sky, a desert landscape entirely fouled by ash and tar, and Stygian lakes of spilled oil and poisoned water. While these angel's- or devil's-eye shots indisputably have the capacity to inspire awe and terror in the audience, they-like apocalyptic imagery in many different media-impose a totalizing visual framework and a simple linear teleology of doom on their material, making it harder for viewers to envision the end of the Age of Oil as something more hopeful than an impossibly huge infernal cataclysm. Herzog's film, whose point of view Szeman describes as that of an alien visitor to Earth, never acknowledges its own major debts to petroleum as a medium, lending the aerial shots some of the bad-faith faux outsider ethos that antienvironmentalists have long criticized in ecological jeremiads made by activists who are typically just as fully enmeshed in petroculture as everyone else. ${ }^{26}$ Nor is there anything "medium" about the aerial shots in the adjectival sense; they elicit extreme emotions at a great distance. Like Edward Burtynsky's sublime (if non-apocalyptic) aerial photographs of oil fields and other sites of industrial extraction, Herzog's helicopter shots "often put the viewer in the position of being overwhelmed rather than in a capacity to effect change."27

\footnotetext{
${ }^{26}$ See Szeman, 38 and 40. The helicopter's shadow does appear for a few seconds in one shot, but this does not register as an important self-referential moment in the film.

27 Joshua Schuster, "Between Manufacturing and Landscapes: Edward Burtynsky and the Photography of Ecology," Photography and Culture 6, no. 2 (2013): 196. Szeman writes that the film's classical score and sublime aerial shots do not empower the viewer's consciousness, but rather leave us with "a sense of the impossibility of overcoming humanity's oil ontology" (41).
} 
This comment applies equally well to the final ground-based scenes of the film, in which an end-of-the-world temporality yields briefly to a comic narrative trajectory, only to finally collapse into a hopelessly cyclical time frame. Just when the film seems to be heading for a happy ending, as teams of American workers manage to put out a fire and install a new well head, capping a furiously blasting gusher, some of the Americans are shown casually and inexplicably setting non-burning gushers on fire - as if, in Herzog's words, "life without fire [has] become unbearable for them" and they have been "seized by madness." What seemed in the helicopter footage like a final apocalypse, the ultimate annihilation of everything, now looks more like an endlessly prolonged catastrophe, one actually kept in motion by the industry tasked with stopping it. The final shot in Lektionen in Finsternis, filmed at night, shows five or more gushers blazing away in the distance, as if the "firefighters" had done nothing at all, or had decided to undo all their labors and begin again. The last scene is introduced with an intertitle, combining Psalms 6:6 and a common German expression, which is translated in the subtitles as "I am so weary of sighing; O Lord, grant that the night cometh." Sighing in despair and wishing for universal "night" are understandable responses to the vast horrors of oil dependence. They will obviously not suffice, however, if we hope to build a viable world after oil.

What I call "petro-Gothic" imagery focuses on rusting abandoned oil rigs (instead of ruined castles), squalid oil-fouled patches of land and water, and the slow, quiet immiseration of birds, people, and other life-forms in spilled crude. It has, as Andreas Malm might say, a different "spatiotemporal profile" than the petro-apocalyptic, since it deals with oil on a smaller visual scale and operates on a humbler (non-epic, non-prophetic) time scale. ${ }^{28}$ However, it too can discourage ethical engagement with petrocultural problems. It does so by framing petroleum and its associated infrastructures as abject, irremediable, out-of-place - and, simultaneously, visually fascinating - monstrosities. Theodore Dreiser's self-consciously painterly 1919 description of a Standard Oil refinery in New Jersey outlines the aesthetic that would be on display in countless petro-Gothic photographs and film scenes over the next century. After speculating about how James Whistler and other artists might represent the refinery, Dreiser observes that "A casual visitor, if he is of a sensitive turn, shudders or turns away with a sense of depression haunting him. It is a great world of gloom, done in lines of splendid activity, but full of the pathos of faint

${ }^{28}$ Andreas Malm, Fossil Capital: The Rise of Steam Power and the Roots of Global Warming (London: Verso, 2016), 38. Malm is referring to material qualities of different energy sources, but this term applies well to representational properties of different ways of seeing hydrocarbons, too. 
contrasts in gray and black." ${ }^{29}$ Later on in the essay, Dreiser takes readers into the heart of this "great world of gloom":

Refuse tar, oil and acids greet the nostrils and sight everywhere. The great chimneys on either hand are either belching huge columns of black or blue smoke, or vapory blue gases... The ground under your feet is discolored by oil, and all the wagons, cars, implements, machinery, buildings, and the men, of course, are splotched and spotted with it. There seems to be no escape. The very air is full of smoke and oil. ${ }^{30}$

Dreiser certainly immerses readers in petroleum as a medium, as in "An intervening substance...through which impressions are conveyed to the senses." 31 His imagery, which tries to communicate the overwhelming power of the refinery's assaults on every human sense, runs directly counter to the virtualizations of matter performed by the myth of Energy. By alluding to famous artists and emphasizing visual elements of the refinery such as "faint contrasts in gray and black" and the different colours of smokes and gases in the air, he goes so far as to foreground petroleum as a kind of unacknowledged artistic medium, albeit one that only a specialized audience (made up of neither "casual" nor conventionally "sensitive" witnesses, but of those with "a taste for the somber") can appreciate. ${ }^{32}$ But this very aestheticization of the most destructive aspects of the refinery, coupled with Dreiser's refusal to mediate between his predominantly native-born American readers and the "thousands" of immigrant refinery laborers he observes working - whom he portrays, in an insultingly deterministic naturalist register, as an anonymous mass of unattractive, unintelligent, subhuman drones who are just as much "victims of Mother Nature" as they are victims of the (unnamed) chief beneficiaries of their labors, John D. Rockefeller and his associates - creates a kind of aesthetic and ethical closed loop. ${ }^{33}$ Readers of Dreiser's essay, like gallery viewers of oil-covered pelican photographs shot in the Gulf of Mexico in 2010, can take satisfaction in knowing that their rarefied "taste for the somber" and the pity they most likely feel for the "dum[b]"34 victims of oil elevate their sensibilities above the feelings of the average gas-guzzling resident of the modern petroworld, who presumably can't be bothered to care about the ecological and

29 Theodore Dreiser, “A Certain Oil Refinery," in American Earth, 187.

${ }^{30}$ Ibid., 189; emphasis added.

${ }^{31}$ Oxford English Dictionary, "Medium."

${ }^{32}$ Dreiser, 187 and 190.

${ }^{33}$ Ibid., 187-91.

${ }^{34}$ Ibid., 190. 
human costs of his or her way of life. However, this sense of satisfaction only further distances viewers from the consequences of their own (ab)use of hydrocarbons; they can feel "right" about oil while continuing to burn it indefinitely, because the substance they "responsibly" pay for and put in their car tanks without spilling it bears no resemblance to the filth covering a poor sea turtle in a photograph. The petro-Gothic thus contributes, despite its normally good intentions, to a sense of what Graeme Macdonald calls "oil's benevolent banality." Macdonald argues that "dystopically tinged images and narratives" inadvertently help legitimate the status quo by "convey[ing] negative projections of a world deprived of oil." 35 I would add that the petroGothic makes business-as-usual petroculture appealing by framing non-banal oil, out-of-control petroleum, as a nightmare. ${ }^{36}$ Furthermore, petro-Gothic images of oily entrapment and oilfield exhaustion and desolation, much like descriptions in Gothic novels of ruined abbeys and characters locked away forever in subterranean dungeons, depend on a sense of inescapability, of temporal and physical stuckness, that obscures the agency and potential resilience of victims, image-makers, and audiences alike. "There seems to be no escape" from oil in the petro-Gothic — and, thus, no viable alternative to a petroleum-centered world and point of view. ${ }^{37}$

\section{Petroaesthetics Beyond Doom and Gloom}

Perhaps in response to the helplessness- and hopelessness-inducing dynamics of doom-and-gloom petroaesthetics, alternative ways of visualizing oil have

35 Graeme Macdonald, “Containing Oil: The Pipeline in Petroculture,” in Petrocultures, 55.

${ }^{36}$ Obviously, it would be no exaggeration to describe an oil spill as an ecosocial nightmare. I am arguing that the petro-Gothic, while not necessarily an untruthful way of representing petroculture, can occlude the much larger and longer-lived nightmare embodied in the businessas-usual "safe" use of hydrocarbons. This is not to say that it is easy to devise alternatives to the petro-Gothic (or to the petro-apocalyptic). Capturing the horror of a highly visible oil spill is one thing; conveying the still mostly unrealized horrors bound up with our invisible carbon emissions, which are produced by activities normally defined as harmless or even virtuous, is a significantly tougher challenge.

${ }^{37}$ Events over the next few years may show that petro-apocalytic and -Gothic modes of representation were in reality the most accurate and/or rhetorically successful ways of depicting oil's externalities. Maybe there truly is no escape from oil, no live future for humanity and the biosphere after the collapse of petro-capitalism, and we should all focus on coming to terms with that grim fact. For now, though, I agree with Macdonald that, while the task of "arresting ... the successful narrative of oil's munificent, modernizing prowess" is "monumentally difficult," it is a crucial and meaningful one to shoulder for petrocritics and those who interpret the world of oil for a wider audience. Ibid., 55. 
begun to emerge over the last few years. Aerial "oilscapes," or god's-eye-view photographs of business-as-usual petroleum extraction and processing sites, are especially interesting in their ways of mediating between viewers/consumers and the usually ignored industries, places, and processes to which they owe both their survival and the prospect of future "climate chaos." 38 The aerial oilscapes (and other petro-photographs) of Edward Burtynsky have received the most scholarly attention so far, with much of it being ambivalent or outright censorious regarding Burtynsky's impacts on viewers. As Joshua Schuster acknowledges in an essay on Burtynsky, "only an aerial shot [of a place like an Alberta bitumen mine] can capture the epic scale of extraction and pollution." 39 Without aerial shots, people in the developed world, most of whom live far from the "sacrifice zones" that make their lives possible, would never witness the vast amounts of destruction involved in bringing the myth of Energy to life. But, Schuster argues, aerial shots "also have the feel of taking a step back and away from the worries of the ground, finding relief in soaring above devastation, suggesting a point of view beyond good and evil and vicariously passing this on to the viewer of the photograph." 40 Catherine Zuromskis faults Burtynsky's petrocultural photographs for producing what she considers a "deeply disturbing" kind of aesthetic paralysis. ${ }^{41}$ As a medium, in other words, the aerial shot risks failing to mediate in an ethically productive way between viewers and the landscapes it represents.

In the case of many of Louis Helbig's aerial photographs collected in the book Beautiful Destruction and on its companion website, the medium may distance viewers from Alberta's bitumen sands ${ }^{42}$ by masking itself as different media entirely: twentieth-century abstract expressionist and surrealist paintings and nineteenth-century colour illustrations, to name a few. This is due not just to Helbig's framing and processing of the images but to the whimsical and

\footnotetext{
${ }^{38}$ On “oilscapes," see Schuster, 208. On "climate chaos," see Dave Pruett, "Global Warming or Climate Chaos: What's in a Name?" HuffPost, March 5, 2015, https://www.huffingtonpost.com/dave-pruett/global-warming-or-climate-chaos-whats-in-aname_b_6802696.html.

${ }^{39}$ Schuster, 209.

40 Ibid.

${ }^{41}$ Catherine Zuromskis, "Petroaesthetics and Landscape Photography: New Topographics, Edward Burtynsky, and the Culture of Peak Oil," in Oil Culture, 300, 304, and 306.

42 I am persuaded by Jon Gordon's argument about the political advantages of using "bitumen" or "bituminous sands" rather than either the pro-industry "oil sands" or the anti-industry "tar sands." Gordon asserts that, by making this change, we can "take a step towards rectifying our relationship to that substance by rectifying our language." Gordon, Unsustainable Oil: Facts, Counterfacts and Fictions (Edmonton, AB: University of Alberta Press, 2015), xxxvii.
} 
bizarre shapes and colours of the bitumen sands, tailings ponds, construction sites, oil slicks, and other photographic subjects themselves. Residual Bitumen, the photograph displayed on the Beautiful Destruction home page, could just as soon be categorized as an oil painting; without the title and other identifying information, it would be difficult to recognize the gorgeous dark-blue swirls and splotches on a white background, with curling lines of iridescence very closely resembling lighter-coloured blue paint mixed in with the darker shades, as photographic representations of hydrocarbon-polluted Suncor tailings ponds in a snowy landscape rather than paint on white canvas or paper. Indeed, on one level Helbig's photograph is merely an aerial view of an "oil painting" actually created by Suncor by processing bitumen and disposing of their tailings in particular ways. Oil corporations never use petro-apocalyptic and petro-Gothic imagery in their self-representations, but it would be easy to imagine a Suncor executive proudly displaying a print of Residual Bitumen on his or her office wall. After all, "beautiful destruction" sounds a lot like "creative destruction," the name for a vision of disruptive economic growth and entrepreneur-driven historical progress embraced by Trump supporters, venture capitalists, and many other upholders of the volatile petrocultural status quo.

But perhaps this critique of Residual Bitumen as a new kind of "artwashing" goes a bit too far. ${ }^{43}$ In view of the general failure of played-out petro-apocalyptic and petro-Gothic visual rhetorics to make much of a difference in terms of how people live with petroleum, perhaps photographs that playfully and beautifully defamiliarize politically polarizing extraction sites such as Alberta's bitumen sands could help open up new lines of communication between fellow citizens who have come to regard each other as adversaries. Maybe the cognitive dissonance produced by viewing aesthetically pleasing images of large-scale environmental and social devastation could help environmentalists rethink some of their ecologically problematic assumptions about natural beauty, and, at the same time, help supporters of fossil fuel extraction face the normally hidden costs of petromodernity. Ordinary people certainly need to be exposed, in a manner calculated to engage rather than offend them, to the fact that modern humanity is aesthetically refashioning the Earth on the largest possible scale. And learning to find beauty in aesthetically

${ }^{43}$ One important way in which Helbig avoids artwashing is by including captions for Residual Bitumen and other images that discuss in detail the toxic by-products and other destructive aspects of bitumen mining. 
and ecologically degraded sites (including, basically, the whole planet) is undoubtedly going to be a crucial survival skill in the Anthropocene. ${ }^{44}$

The potential of Helbig's aerial oilscapes to foster communication across charged political boundaries, to open up space for new ways of viewing petroculture from within, and to reeducate viewers in the aesthetics of the Anthropocene is rooted in a different approach to human-nonhuman relationships than the fundamentally anthropocentric orientations of the myth of Energy on one side and of the petro-apocalyptic and petro-Gothic on the other. ${ }^{45}$ Helbig's photographs seem especially successful when they show bitumen mining neither as the triumphant human rendering of brute, meaningless matter into Energy nor as the simple and total human annihilation of pure Nature but as the kind of "event-space and...style of structuration" that Jane Bennett, following Gilles Deleuze and Félix Guattari, terms an assemblage. This is an "open-ended collective" consisting of nonhuman as well as human agencies and materialities, a dynamic field of relationships between beings, things, forces, and cycles that features uneven distributions of power and lacks a "central head" but nonetheless exhibits a kind of (emergent and unpredictable) group will that has the power to "make something happen."46 (Interestingly, the main example Bennett provides of an "agentic assemblage" has to do with energy. She describes the electrical grid as a "volatile mix of coal, sweat, electromagnetic fields, computer programs..., fantasies of mastery, static, legislation, water" and so on.) $)^{47}$

As Bennett admits, the decentering of human subjectivity and agency inherent in the idea of the assemblage can make it very hard or even impossible to weigh questions of responsibility for what a given assemblage does, precisely assigning the correct amount of culpability to each of the particular "actants" that comprise it. ${ }^{48}$ But I agree with Bennett that "[a]n understanding

${ }^{44}$ These points were inspired by Helbig's comments on his purposes, including the avowed goal of bringing together in his book a wide range of competing voices (including Indigenous and French-Canadian voices in their own languages). I use the term "Anthropocene" as a kind of shorthand, fully aware of the major - perhaps, as Matt Hern and Am Johal put it, "fatal"-flaws that inhere in the designation. See Hern and Johal, Global Warming and the Sweetness of Life: A Tar Sands Tale (Cambridge, MA: The MIT Press, 2018), 52-63.

${ }^{45}$ On the anthropocentric aspects of environmentalism — starting with the problematic term "environment"—-see Jane Bennett, Vibrant Matter: A Political Ecology of Things (Durham, NC: Duke University Press, 2010), 111.

${ }^{46}$ Ibid., 23-24.

${ }^{47}$ Ibid., 25.

${ }^{48}$ Ibid., 28-38. As Bennett notes, Bruno Latour defines an actant as a human or nonhuman "something" that performs an action whether or not it consciously intends to do so. Ibid., 9. 
of agency as distributive and confederate" has many advantages over the often ineffective or violence-promoting "politics of blame." 49 In the case of bitumen extraction, using doom-and-gloom imagery and narratives to cast blame for the destruction exclusively on a corporation such as Suncor, or on Alberta's government, would surely bring a certain primal satisfaction. But it would fail to do justice to the enormously complex distribution of responsibility that actually characterizes the assemblage known as petroculture, and it would (thus) further antagonize the kinds of working-class builders/defenders of petroculture and global warming skeptics who are presently standing in the way of large-scale transitions to alternative energy - but who also often have the skills needed to make these transitions a reality. ${ }^{50}$ On a related note, the disparagement of oil's tremendous "thing-power" conveyed especially by petro-Gothic imagery (in which petroleum is not portrayed as an amazingly potent and seemingly will-full energy source "that acts with a force suggestive of a form of life" but, rather, as nothing but disgusting, immobilizing matter) unintentionally colludes with the myth of Energy in making it hard to care for oil itself. ${ }^{51}$

By respecting oil's unpredictable agency and surprising beauty, Louis Helbig's oilscapes chart a middle course between a) myth-of-Energy approaches that affect a love for oil but actually show contempt for it by promoting its constant annihilation and $b$ ) environmentalist framings that express nothing but antipathy towards oil while secretly revealing their producers' guilt-ridden dependence on it. I would argue that Helbig's aerial vantage point is an asset rather than a liability because, instead of foregrounding human power by way of the usual ground-level images of smoke-belching refineries and gigantic earth-moving machines, it humbly repositions humans as one set of actants among many others, including pipes, rivers, toxic waste, trees, wind, roads, huge piles of metal trash, and more. To revisit Joshua Schuster's claim about Burtynsky’s aerial photographs,

\footnotetext{
49 Ibid., 38.

50 These points are informed by Hern and Johal's efforts throughout their book to take seriously the perspectives of bitumen industry workers and others, including Hern's own daughter, who have benefited financially from Canada's oil boom. Hern and Johal argue that "People who are deeply concerned about global warming ... need to talk with people who occupy all kinds of positions that are not ours, and to listen and argue carefully." They ground this imperative in the knowledge that "We're all implicated in these extractivist ideologies of fossil fuels, biocollapses, and species extinctions: we're all burning most everything we can get our hands on" (Hern and Johal, 84).

${ }^{51}$ Bennett does not apply the term "thing-power" to oil, but it makes very good sense to do so. See Bennett, 2-17. On oil's lifelikeness, see LeMenager, 6.
} 
sometimes a point of view "beyond good and evil" can be helpful. ${ }^{52}$ This is particularly true when we're dealing with people and a substance whose vilification by "a politics devoted too exclusively to moral condemnation," in Jane Bennett's words, has helped create a monumental impasse. ${ }^{53}$

Bruno Latour has argued that modern humans, learning from Victor Frankenstein's disastrous rejection of his creature, must teach themselves to "love [their] monsters," meaning that we must stop pretending that we can emancipate ourselves from the material world and, instead, start caring for the unintended and often hated by-products of modernity's dreams of emancipation. ${ }^{54}$ Helbig's oilscapes enact this kind of love-which is very different from the addictive/abusive "bad love" 55 that keeps petroculture running - by highlighting the thorough entanglement of the human and the nonhuman and by exposing viewers to the unexpected and unintentional beauty of substances and places that they have been taught to think of as purely monstrous (or to ignore altogether). Consider Helbig's Alluvial Fan, a bright satellite-image-like photograph of some tailings "consisting of water, sand, clay, industrial solvents and residual oil" that form a copper-coloured shape resembling a river delta on an alien planet. ${ }^{56}$ The alluvial fan itself, its shockingly "unnatural" colour, and the pond it drains into are all products of human activities, but the fan's network of watercourses turns the site into an assemblage comprising many different actants - petroleum, bulldozers, mud, human workers, gravity, time, Canadian environmental regulations, the global price of oil at a given moment, sunlight - rather than a simple indictment of human destructiveness. Alluvial Fan reminds me that a famous literary assemblage, Henry David Thoreau's ecstatic meditation in the chapter "Spring" in Walden on the wildness of the human body, language, and culture, was inspired not by the sublime view from a wilderness mountaintop but by the lowly, even "excrementitious," interplay of solar energy, water, and sand in a

\footnotetext{
52 Schuster, 209. My views on Helbig's photographs have been influenced by Schuster's discussion, on this same page, of how aerial shots can productively emphasize the "agency of machines, new technologies, and other nonhuman actors."

53 Bennett, 38.

${ }^{54}$ Bruno Latour, "Love Your Monsters: Why We Must Care for Our Technologies as We Do Our Children," The Breakthrough, no. 2 (2012).

${ }^{55}$ LeMenager, 11.

${ }^{56}$ Helbig, "Alluvial Fan."
} 
"deep cut" made through a hill on the edge of Walden Pond to accommodate the loud, smoky steam trains of the Fitchburg Railroad. ${ }^{57}$

Alluvial Fan and Helbig's other oilscapes embody a quietly revolutionary commitment to finding beauty in places, substances, and processes that both petro-corporations and environmentalists render abject: industry by hiding them behind tall fences and the myth of Energy, environmentalists by representing oil not as a medium but as an ugly, "unnatural" blight on Nature. Helbig's approach invites both practitioners and scholars of petroaesthetics to make room in our conceptualizations of beauty for substances and sites that most of us have (rather guiltily?) shunned, helping us come to terms with beautiful/destructive changes to Earth that all modern humans have a share of responsibility for producing. I can't say whether this photograph will inspire any viewers to "love [their] monsters" by volunteering to help restore areas ravaged by bitumen mining, but it seems to me that Helbig's respectful handling of petroleum models a more effective strategy for image-makers who want to participate in energy transitions than that of simply demonizing oil. (I say "participate in energy transitions" rather than something more strictly representational, such as "promote," to signal the "transitionality" of artworks such as Alluvial Fan; this concept encompasses both their status as meaningful transitions in their own right in the way that they transform Energy and their material-discursive entanglement with the world of solar panels, carbon taxes, Teslas, and so forth.)

Still, however successful they may be in opening up new ways of seeing petroleum as a medium of transformation, destruction, and strange beauty, Helbig's photographs draw very little attention to the petro-materiality of the medium. They have little to "say" about their imbrication in petroculture as objects made with hydrocarbon-based materials and produced using fossil energy, and as representations of the modern hydrocarbon-centric visual paradigm, in which aerial and satellite shots have become as "natural" as melting glaciers. Helbig, like Burtynsky, offers us views of oil, not views that critically and self-consciously peer through it. For that kind of intimacy with petroleum - a marriage of theme and material — we can look to emerging art forms such as Warren Cariou's "petrographs" and the oilscapes of Kathleen Thum.

Petrographs are small photographic images of bitumen extraction, refining, and disposal sites produced on polished metal plates using processed

${ }^{57}$ Henry David Thoreau, Walden; or, Life in the Woods (Boston, MA: Beacon Press, 2017 [1854]), 285-89. 
bitumen itself, in addition to kerosene and lavender oil. Warren Cariou says that his goal in making petrographs is to "use oil in a way that doesn't make it disappear, that in fact just keeps it there in front of you." ${ }^{58}$ Seeing bitumen sites through the medium of bitumen, in Cariou's view, places his audience in a temporary direct relationship with oil that has the potential to "make them reflect on other ways they are in a relationship with it" - a relationship that we normally refuse to acknowledge as such. ${ }^{59}$ Elysia H. French, following Jon Gordon, points out that the small size and reflectiveness of Cariou's petrographs contribute to this work of relationship-building and -revealing; as viewers move the shiny plates around, trying to make out the full images, they see reflections of their faces, too. They thus become "implicated in the scene" and "are asked to acknowledge and recognize their participation in the culture of oil." ${ }^{60}$ When they view Cariou's wonderfully named petrograph Tar Selfie (2014), the artist becomes co-implicated with them; the viewers and the artist face oil together not just by directly confronting the dark realities of our position on Earth but by acknowledging oil's "face" as a material, agentive presence $^{61}$ rather than an economic abstraction. In the image, Cariou owns up to his "embeddedness in the politics and economics of oil," and oil seems to claim him as its own by masking his forehead and cheeks. " In Cariou's hands, bitumen becomes an artistic medium that can be used for "something other than fuelling the fantasies of modernity"; it becomes something more than just fuel, more than Energy. ${ }^{63}$

\footnotetext{
${ }^{58}$ Quoted in Elysia R. French, "Transformations of Oil: Visibility, Scale, and Climate in Warren Cariou's Petrography," RACAR: revue d'art canadienne/Canadian Art Review 42, no. 1 (2017): 71.

59 Ibid.

${ }^{60}$ French, 68.

${ }^{61}$ Of oil's agency, Allan Stoekl writes that "we are interpellated by oil, by its demands and inconsistencies. As with the auto, we care for it, cultivate it, propagate it, rouse it from its slumber by freeing it from shale or melting it from sand, love it, abuse it, waste it. That is what we do, what we are. We are subjects of, and subjected to, the energy slaves provided by oilwe are inconceivable without those slaves, their demands are our demands" (Stoek1, 41).

${ }^{62}$ Warren Cariou and Jon Gordon, "Petrography, The Tar Sands Paradise, and the Medium of Modernity," The Goose 14, no. 2 (2016): 22.

${ }^{63}$ Ibid., 16.
} 


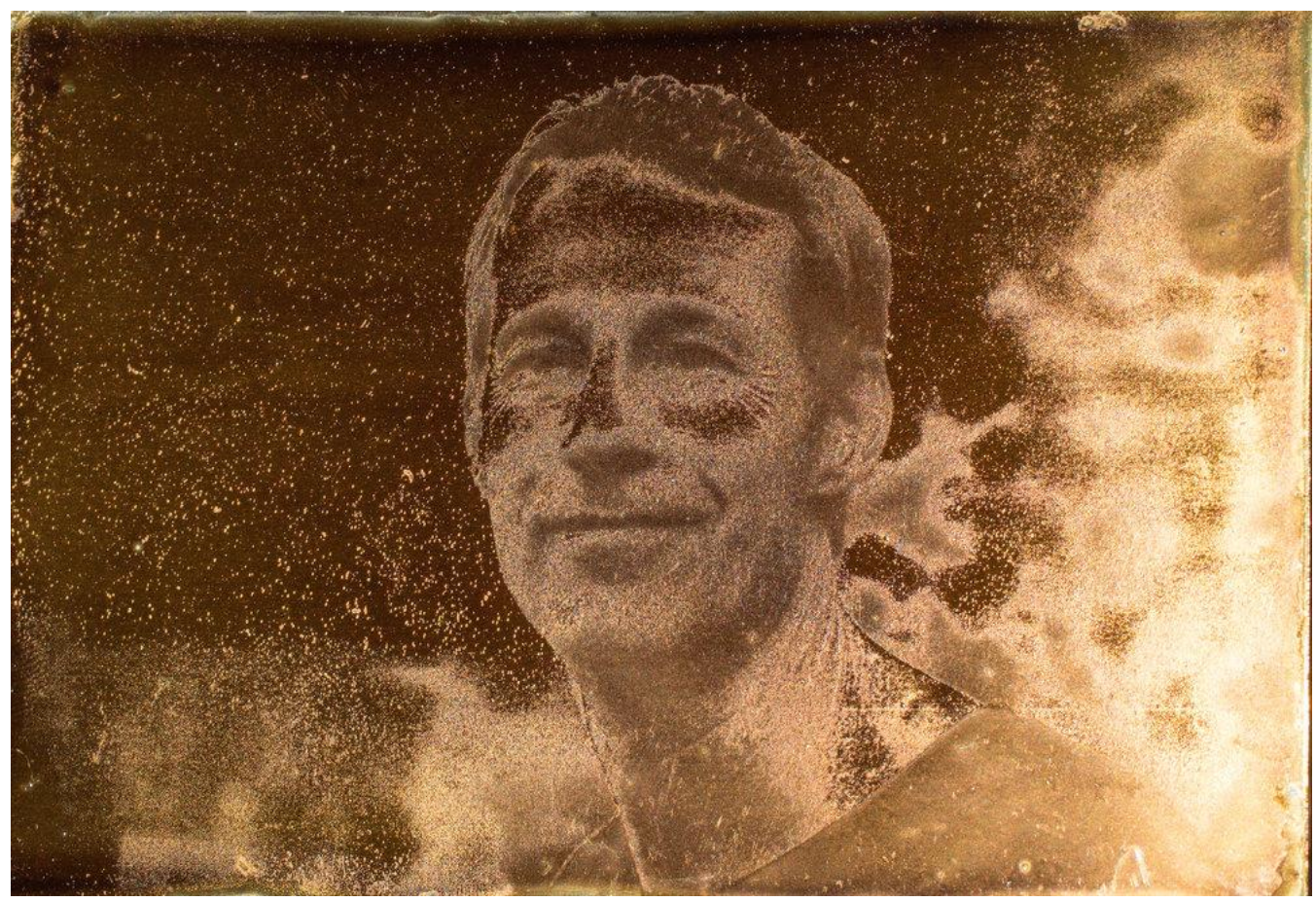

Figure 1: Warren Cariou, Tar Selfie, 4" x 6" Petrograph on Aluminum. V.1, 2014. Courtesy of the artist.

The degree of attentiveness to petroleum-as-medium that one sees in Cariou's petrographs is hard to find elsewhere in the world of contemporary art. As Mel Evans shows, the art world is a mostly unacknowledged petroculture just as dependent on oil as any other part of modern civilization, despite its surface unrelatedness to the world of freeways, muffler shops, and poisoned river deltas. However, like Cariou's petrographs, Kathleen Thum's experiments with unprocessed petroleum, used motor oil, and other hydrocarbons rarely seen by most residents of petrocultures in everyday life (as well as her experiments with conventional hydrocarbon-based paints and inks) invite viewers into visual relationships with normally abject materials and scenes in an effort to help us see how our hidden-but-vital relationships with hydrocarbons are transforming the planet, and transforming $u s$.

I first became acquainted with Kathleen Thum's work at the 2016 Petrocultures conference at Memorial University of Newfoundland, where Thum and I spoke on the same panel. At that point, I had been thinking for some time about how hydrocarbons' abject status in both industrial and environmental discourses restricts our culture's ability to care about these substances themselves (as distinct from caring about biosphere-wrecking 
carbon emissions and the human and nonhuman victims of the fossil fuels industry), and how this abjectness limits our capacity to want to keep hydrocarbon deposits in the ground. Thum's descriptions of using liquid hydrocarbons as artistic media fired my imagination, as did the photographs she displayed of her representations of intestine-like tangles of pipelines burrowing into and erupting from landscapes that sometimes resemble skin and organs as much as they call to mind rocks and dirt. More than most other visual artists I was aware of, Thum was invested in exploring the lively dimensions of petroleum and the oiliness of modern human life. ${ }^{64}$

In December 2017, my daughter Autumn and I drove ${ }^{65}$ to the Appalachian foothills of South Carolina to see Kathleen Thum's work in person. We attended the opening of an exhibition called Unnatural History at the Spartanburg Art Museum, where some of Thum's works were being shown, and visited her studio a few miles west of Spartanburg, where she generously introduced us to several works in progress and told us about methods she is devising for working with and representing petroleum.

At the museum, I immediately noticed her largest work, Carrying Capacity (2014): a 12x17-foot wall installation executed in ink and acrylic on hand-cut paper. I was struck not just by its size but by the way it troubled the usual boundaries between work of art and display space. An unframed mass of paper pipelines and spills/clouds taking up almost an entire wall of the museum, Carrying Capacity is made up of many different parts that hover at slightly varying distances from the wall. Curling paper edges jut out at unruly angles, enhancing a sense of fragility that is surprising to find in a representation of petroleum infrastructure, whose hardness, permanence, standardization, and filthiness are often contrasted in environmental imagery

${ }^{64}$ At Petrocultures 2016 I was introduced to the work of two other artists who are experimenting in fascinating ways with petroaesthetics: Ruth Beer and Sue Jane Taylor. Beer's interactive oil-related exhibits are designed to open up conversations about, for instance, the possible impacts on coastal ecosystems and Indigenous cultures in British Columbia of the proposed (and, as of 2016, rejected) Enbridge Northern Gateway pipeline/tanker project. Taylor has, among other things, been visiting offshore rigs since the 1980s, documenting rig life in drawings, etchings, and sculptures of Scottish oil workers and the technologies they employ to extract petroleum from beneath the ocean floor in the dangerous waters of the North Sea. In 2018 I met two artists besides Kathleen Thum who use unprocessed hydrocarbons as media One was Elia Vargas, a California-based artist, some of whose installations focus on crude oil's long history as a medicine before it became a world-altering source of power. The other was Genevieve Robertson. She works with a blend of bitumen, seawater, and gouache to imagine "amorphous forms that exist between biology and geology, waste and treasure, petrification and liveliness, emergence and decay." See Robertson, Language for the Wrack Zone.

${ }^{65}$ Yes, using gasoline (but at least the car was a hybrid). 
with the wild unpredictability, purity, and vulnerability of nature. Thum showed me that she had painted the back of Carrying Capacity magenta, which helped explain why the artwork projects a bright and nervous, rather than lugubrious, energy despite the masses of black and gray forms; the magenta backing colours the shadows of the pipelines and other shapes cast on the wall. This play of shadow and reflected colour dynamically sets off the work's fluid transitions between easily recognized signifiers of oil (messy blacks and grays) and unexpected patches of rainbow-like yellows, oranges, pinks, blues, and greens, which gesture not only to the iridescence of spilled oil but to the future of life in a badly damaged but still viable biosphere.

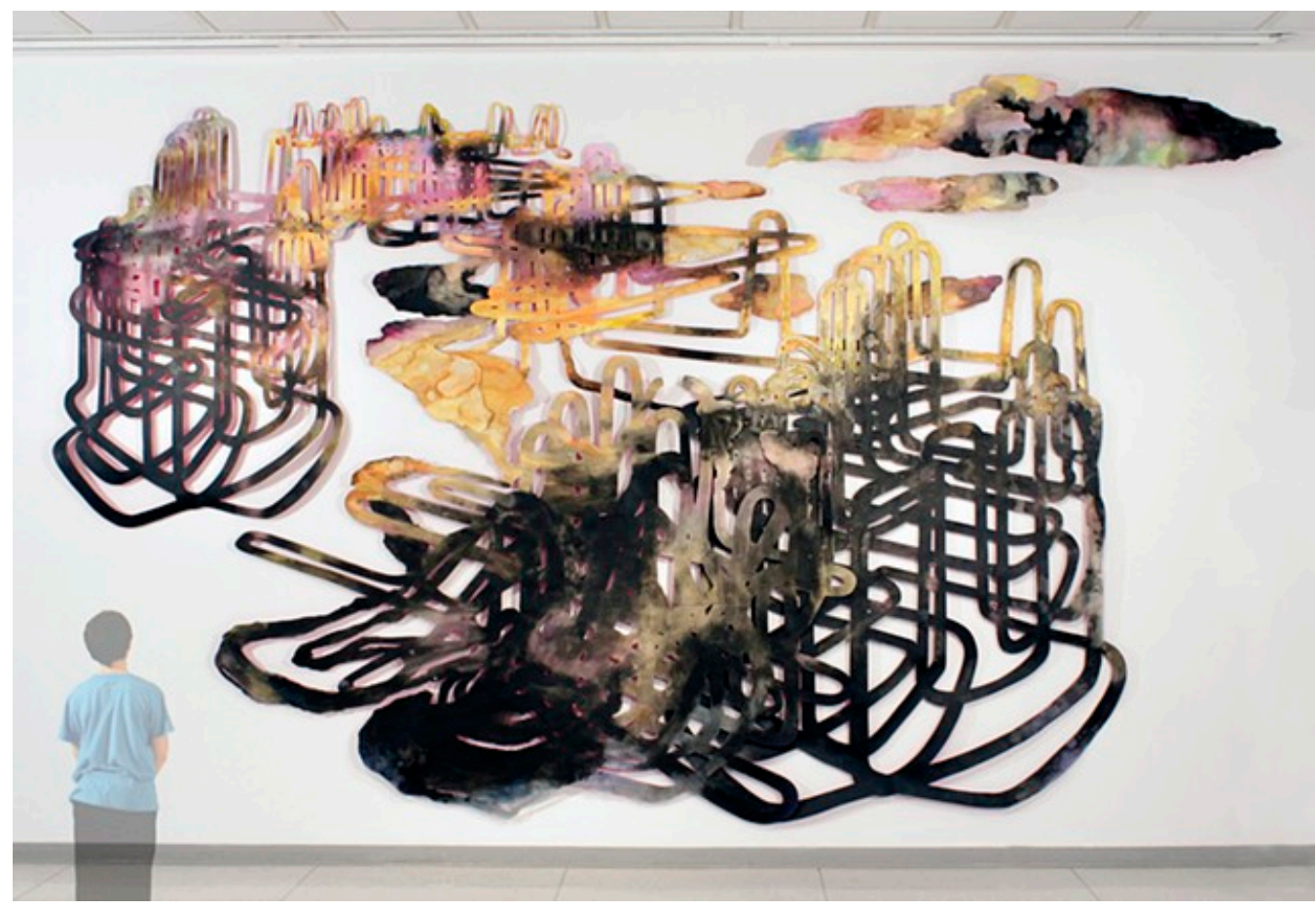

Figure 2: Kathleen Thum, Carrying Capacity, Ink and Acrylic on Hand Cut Paper, $12 \mathrm{ft} x 17 \mathrm{ft}, 2014$. Courtesy of the artist.

Carrying Capacity's title - as opposed, say, to Edward Burtynsky's neutral titles, such as Oil Refineries \#15-raises troubling questions about how many more petro-humans the planet can provide for, and how much more extraction, refining, burning, and spilling of petroleum Earth can bear. Unlike the smooth-running refineries in Burtynsky's oil photographs, Carrying Capacity features what appears to be a meltdown in the bottom center part of 
the work, as a snarl of exhausted-looking pipelines slumps over and spills the pipes' burden of oil, perhaps auguring a cascading series of collapses in the rest of the system. As a microcosmic vision of Earth and/or global petroculture in the Anthropocene, Carrying Capacity is not a conventionally pretty picture. Nor, however, is it a conventionally ugly one. Eschewing the confident linear vectors of petro-apocalypse, the despair-inducing immobilizations and victimizations of the petro-Gothic, and the homi-/ecocidal mystifications of the myth of Energy, Carrying Capacity opens up a weirdly appealing, nonsublime, uncertain space for the contemplation of an uncertain future. Judging by the spirited conversation Thum had with a number of curious patrons at the exhibition opening, Carrying Capacity and the smaller works she showed at the museum succeeded in evoking more productive responses than the guilt and numbness that, as discussed above, are associated with traditional petroaesthetics.

The next morning, we visited Thum's studio in the small town of Liberty. This visit provided me with a wealth of opportunities to reflect on how art can generate new ways of seeing hydrocarbons and new forms of dialogue - not just between people but between us and hydrocarbons themselves. Given the bitterly polarized state of energy politics in the U.S. and the long history in Western countries of regarding hydrocarbons as nothing more than energy sources and feedstocks for industry on one hand and hateful pollutants on the other, both human-human and human-hydrocarbon dialogue are tough. Thum told us about the unexpected hostility she encountered during a recent residency in Wyoming when she tried to talk about the coal industry with locals. She also discussed the challenges of working with crude oil and used motor oil to create the screen print 190,000 Miles (2017) (see Figure 3). The copies we viewed (one of which she gave us, and which I am looking at while writing these lines) bear witness to these difficulties. The thicker lines, executed with crude oil, bleed outward and seep through the heavy paper; on one of the prints, a stray drop of oil attests both to the uniqueness of this particular artifact and to the unruliness of unprocessed liquid hydrocarbons as a medium compared to standard mineral- and hydrocarbon-based inks and paints. The piece's colours likewise refuse to play by the rules. The crude oil is not deep black but a somewhat shiny golden-brown, and the used motor oil is light $\tan$.

However, petroleum's unruliness as an artistic medium contributes to the gestalt-shifting work of the image. A kind of visual riddle, 190,000 Miles first appeared to me as a random assortment of mostly crooked solid and dotted lines. But an uncannily familiar curve and some claw-like shapes at the densely besquiggled bottom section of the print (“Are those Texas and Louisiana?”) 
revealed that we were looking at a carefully rendered visualization of the approximately 190,000-mile U.S. network of crude oil and processed petroleum pipelines. Excluding all place names, conventional symbols, and indications of taken-for-granted political boundaries and topographies, the print is a map - one designed not to give viewers a sense of control over the landscape but, paradoxically, to disorient them, and then to reorient them vis-àvis their situatedness in U.S. pipeline petroculture. This is a vast shadow geography that sustains almost everyone in the country, but one about which very few people know anything at all.

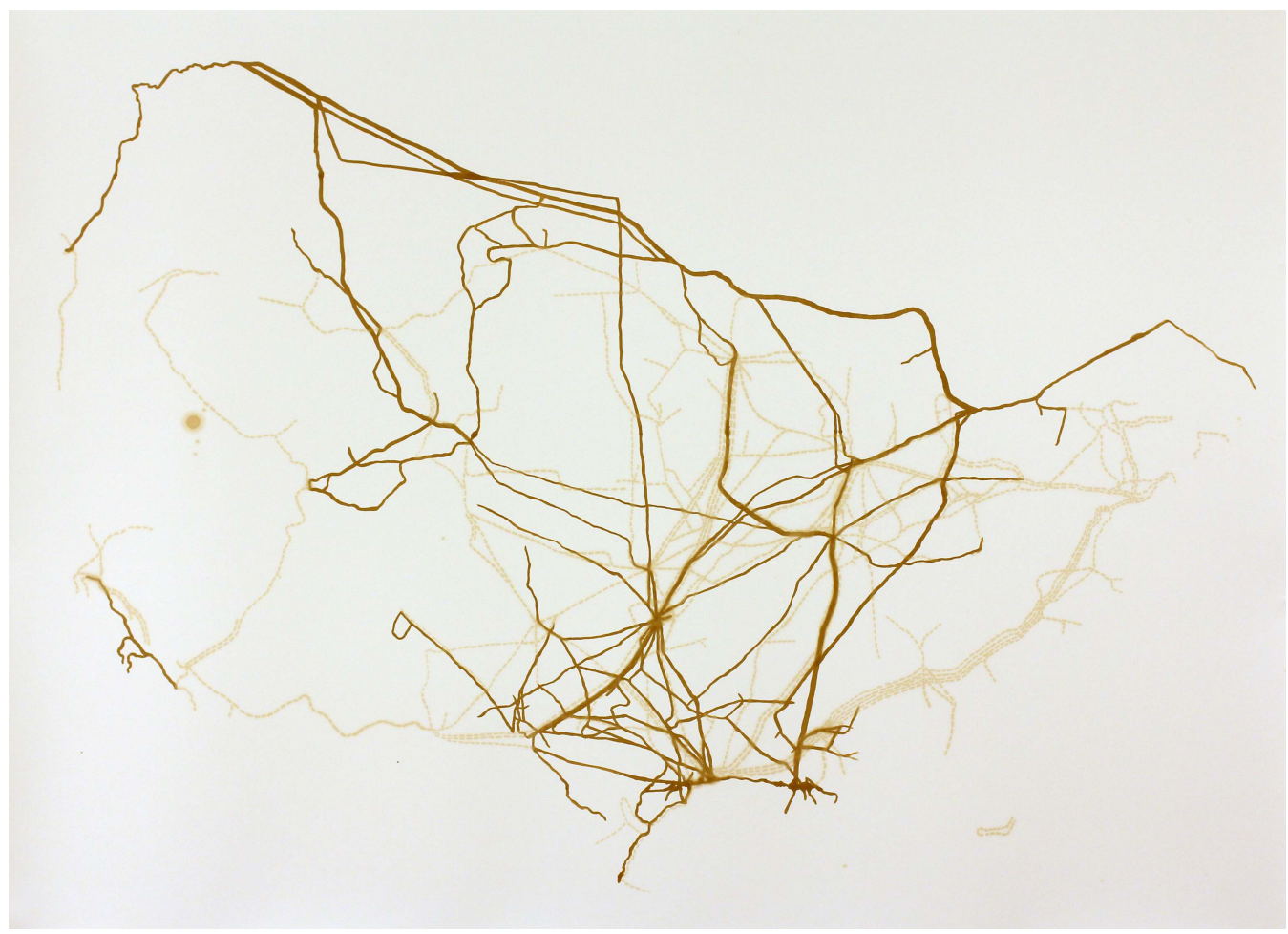

Figure 3: Kathleen Thum, 190,000 Miles, 2017. Courtesy of the artist.

Thum's decision to use petroleum itself, a metonymic rather than metaphorical stand-in for the pipelines, contributes to this disorientation/reorientation process in several ways. First, since pipelines are designed to keep petroleum safely sequestered within a kind of self-contained industrial ecosystem, leading to oil's normal invisibility, 190,000 Miles constitutes a prima facie challenge to this everyday hiddenness and to the oil 
industry's proud assertions of "99.999\%" safety rates. ${ }^{66}$ From the perspective of both oil corporations and environmental groups, unrefined petroleum is never supposed to be seen by consumers in a petroculture; seen oil is spilled oil, oil out of place. (By the same token, used motor oil is supposed to disappear to the great "Away" where all unwanted things end up.) 190,000 Miles essentially and transgressively turns pipelines, and the continent they are part of, inside-out. In doing so, the print does not just represent pipelines, but situates itself, along with viewers, in petroculture. Furthermore, the bleeding edges of the crude oil (pipe)lines, when considered alongside the similarity of many of the lines to cartographic representations of rivers, metonymically problematize both a) the hard nature/culture dualism that actual pipelines materially and discursively instantiate and b) pipeline boosters' fantasies of near-perfect containment - which, no matter how effective pipelines really are at keeping oil from spilling in transit, obscure the catastrophic problem of uncontained carbon emissions produced by the "safe" processing and burning of oil. ${ }^{67} 190,000$ Miles thus denaturalizes petroculture by exposing a normally invisible second-nature infrastructure that we unconsciously depend on every second of the day, showing that it is actually a gigantic but flawed human system - a system that the print does not directly condemn, but in which, rather, it actively and critically participates, modeling a multidirectional relationship where consumers have been trained to see nothing but a one-way domination of nature (or, in many cases, to see nothing whatsoever).

Saying that the print denaturalizes petroculture is not the same as saying that it renders oil unnatural in a petro-apocalyptic or petro-Gothic sense, as if petroleum were an extraterrestrial poison concocted with the goal of destroying the world or defiling a supposedly pristine nature. Looking at the print, it is impossible to accept fully the industrial view of pipelines as "energy lifelines"-majestic human engineering conquests over nature, or else harmless artificial blood vessels in a civilization-scale cardiovascular system that is as inevitably a part of human life as the flow of blood through our own veins. ${ }^{68}$ On the other hand, it is impossible to entirely reject this view. Confronting crude oil "face"-to-face as a naturally occurring but human-extracted material substance, rather than unthinkingly consuming it as Energy, forces us to come to terms with petroculture's weird interwinements of human and nonhuman

${ }^{66}$ This credibility-straining statistic comes from the section of the American Petroleum Institute's Pipeline 101 site called "Are Pipelines Safe?," https://pipeline101.org/Are-PipelinesSafe.

${ }^{67}$ See Macdonald, 42.

${ }^{68}$ On pipelines as "energy lifelines," see the home page of the American Petroleum Institute's Pipeline 101. 
energies and agencies. Looking at a map of tens of thousands of miles of pipelines makes us realize that this enormous infrastructure - undergirding and overspreading deserts and prairies, forests and wetlands - will, for all practical purposes, be a part of nature forever (as much a part of it as the carbon from hundreds of billions of barrels of burned oil). But when the pipelines are rendered using petroleum itself on a non-sublime scale ( 38 by 54 inches, in the case of 190,000 Miles), this depressing Anthropocenic insight is tempered by the realization that pipeline assemblages do not merely act upon nature, but are made of earthly materials and themselves possess certain lifelike qualities. On her website, Thum writes that her pipelines form "growing and altering landscapes," and "even becom[e] their own living entities enmeshed with the landscape." 69 Perhaps, as her work evolves, the pipelines - rather like the living (or undead?) oil rigs in China Miéville's story "Covehithe"—will start slithering around more, and even produce baby pipelines.

Indeed, many of Thum's pipeline structures resemble masses of writhing snakes. In Burn Baby Burn (2016), a twisting knot of tubes breaks off from Carrying Capacity (which serves as the main part of the installation) and seemingly crawls of its own volition across the floor and part way up the adjacent wall, blasting out a cloud of flame and smoke like an angry industrial dragon. It makes sense to interpret this part of the installation as a commentary on the insane logics of capitalist economic growth and petroleum-driven sprawl, but the absence of human figures underscores the fact that these are more than human-cultural phenomena. Thum's installation, like the artistic and ecological "monsters" discussed in the collection Arts of Living on a Damaged Planet: Ghosts and Monsters of the Anthropocene, captures an ambivalence at the heart of our era's unprecedented version of monstrosity: Anthropocenic monsters are "the wonders of symbiosis" revealed by twenty-first-century science and they are "the threats of ecological disruption" posed by modern worldviews and technologies. ${ }^{70}$ Carrying Capacity welds together the wondrous and the terrifying. It makes visible petroculture's status as a fascinating assemblage to people who have been taught to think of humans as the only actants and petroleum and hydrocarbon infrastructure as nothing but will-less matter, but the installation simultaneously confronts viewers with the prospect of a nonhuman, non-sentient agency running amok. Thum's attentiveness to oil's agency in Carrying Capacity and similar works raises

69 Thum, Portfolio: 2017 to 2013.

${ }^{70}$ Heather Swanson, Anna Tsing, Nils Bubandt, and Elaine Gan, "Bodies Tumbled into Bodies," in Arts of Living on a Damaged Planet: Ghosts and Monsters of the Anthropocene, edited by Anna Tsing, Heather Swanson, Elaine Gan, and Nils Bubandt (Minneapolis, MN: University of Minnesota Press, 2017), M2. 
tough, necessary questions about the balance of power in human-hydrocarbon relationships. What does it mean to be alive, and to say that you inhabit a living world, if you spend all your time in hydrocarbon-heated and-cooled buildings (constructed with hydrocarbon-fueled machinery) staring at hydrocarbonpowered screens, or sitting in hydrocarbon-burning vehicles on asphalt roads, and every calorie you ingest is produced and transported using fertilizers, pesticides, and fuels derived from the geologically transmuted remains of organisms that died millions of years ago? What kind of "living world" is it if every cell of every tree in the world, even in the most remote wilderness areas, is partly made of atmospheric carbon from burned fossil fuels? Do we use oil, or does oil use us?

The answer in Thum's work is "both"-although "use" is not entirely correct in this context, since petroleum and humans transform each other dramatically in the process. Her work both respects oil's otherness and shows how oil and humanity have become what Donna Haraway might call weird kin, getting entangled even on a microscopic level. (Works such as Accumulation [2013] and Multilateral [2014] feature small, nearly-empty reservoirs of oil that look like parts of a cell or little glands in the human body.) While she uses both visual and linguistic disease metaphors to depict the current state of the Earth, Thum avoids the twentieth-century mainstream environmentalist tendency to pathologize humanity as, for instance, "a great unthinking, unfeeling cancer" on the world. ${ }^{71}$ Earth is certainly "becoming cancerous," in Thum's words, but this metastasis is a product of the interplay of human and nonhuman forces. Many of Thum's pieces stage this interplay through a kind of visual multistability as they shift back and forth between resembling pipelines and resembling intestines or tumours or blood vessels (or snakes). Slope Scarp (2013) depends both on this kind of human/nonhuman multistability and on a scalar multistability, as it shows Earth in microcosm, somewhat like the illustrations of tiny planets in Antoine de Saint-Exupéry's 1943 classic The Little Prince (but without human figures). Slope Scarp (see Figure 4) depicts a miniscule, diseased, human-heart-shaped planet, veined or wired with pipelines, that seems to be drilling and burning itself away to nothingness - an impression supported by the bleeding-through in the foreground of the background image (executed on another semi-transparent sheet of Mylar), as if the heart-planet is haunted by its former, larger self as it

${ }^{71}$ As the valedictorian of her college's Class of 1969, Stephanie Mills used this metaphor in her commencement speech, in which she warned the audience of what she viewed as humanity's "impending extinction" due to overpopulation. Mills, "Mills College Valedictory Address," in American Earth, 469-72. 


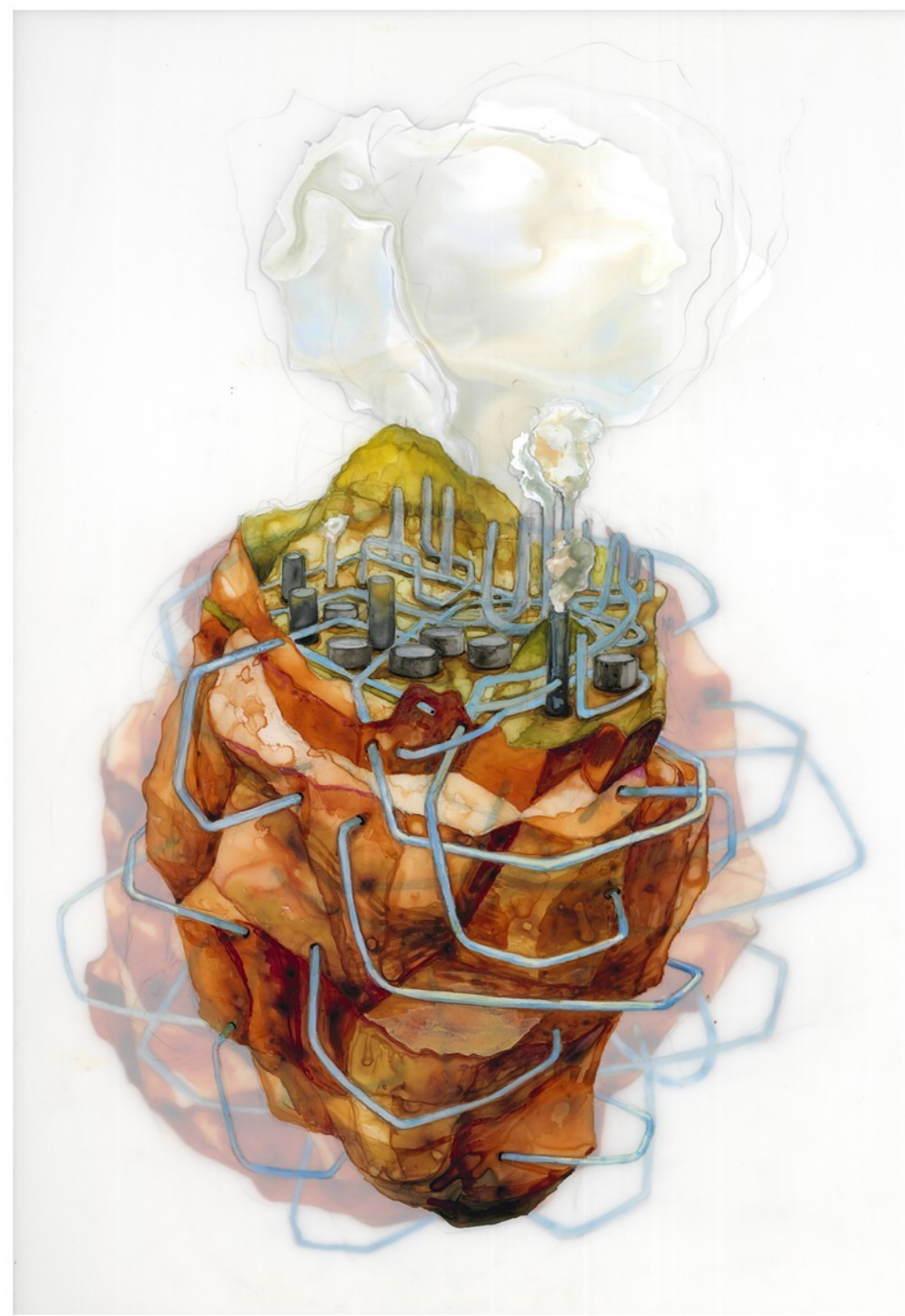

Figure 4: Kathleen Thum, Slope Scarp, Ink and Graphite on Layers of Mylar, $21 " x$ 16", 2013. Courtesy of the artist.

continues to shrink. The ghostly presence of the background image also lends an illusion of motion to the heart-planet, as if, while it will never be what it once was, it still has a few beats left in it. This kind of dynamism keeps even the most openly polemical of Thum's works, such as Drill Baby Drill (whose 
title comes from a popular pro-fossil-fuels slogan that vice presidential candidate Sarah Palin encouraged crowds to chant at Republican campaign rallies during the 2008 U.S. election), from devolving into simple artistic diatribes against conservatives, President Trump and his planet-trashing administration, the oil industry, or humans in general. Thum's clear-eyed appraisals of our precarious heart condition in petroculture make it hard for viewers not to own up to their "ultradeep" 72 emotional, bodily, and earthly investments in hydrocarbons, as well as to hydrocarbons' shaping presence in every nook and cranny of human being.

\section{Conclusion}

Facing oil as Warren Cariou and Kathleen Thum do may sound depressing. However, I found the experience of facing oil (and coal) in Thum's studio in Liberty oddly liberating. "So that's what you are," I thought, as Autumn and I examined Thum's bottle of Late Cretaceous Niobrara Shale crude oil and hefted a chunk of coal, both from Wyoming. After spending a whole lifetime in a world of Arctic air in July and strawberries in December, and after thirty years of filling up gas tanks and using motor oil, it was, incredibly, only one of a handful of encounters I have had with unprocessed hydrocarbons. The experience of placing these materials geographically, smelling the shoe polish scent of the oil, getting some of it on my fingers, and comparing Thum's drawing of the coal to the piece in my hands - seeing hydrocarbons through a new medium that partners with these substances instead of simultaneously using and disavowing them - was a bit like the moment in a horror movie when the Thing in the Shadows finally enters the light. The creature is still dangerous but it is much less monstrous; it may even start to look uncannily familiar. For a little while, anyway, hydrocarbons went in my mind from being an impossibly huge, abstract global problem to mattering. It became easier to imagine petroculture transitioning to a renewable energy culture because I was witnessing an actual transition in progress. The invisible was becoming visible; the abject was becoming art; anonymous commodities were attaining the dignity of subjects of portraiture. I caught a brief glimpse of a past when raw petroleum was medicine, and of a possible future in which hydrocarbons may be defined less as fuels than as remarkable fossil remnants of a vanished biosphere, and may thus be accorded something like the respect that we

${ }^{72}$ LeMenager borrows this highly resonant term from modern petroleum industry discourse, where it is used to describe wells that are being drilled deeper than ever before in pursuit of an ever-shrinking supply of untapped oil deposits. 
currently show to dinosaur skeletons in museums. ${ }^{73}$ Is this the future that will really materialize? Only if we keep finding better ways, on the largest and smallest of scales, to make Energy matter.

\section{Acknowledgements}

Many thanks to Warren Cariou and Kathleen Thum for permission to reproduce their work here; I especially appreciate the time Kathleen took to introduce me to several of her ongoing projects. The University of North Florida supported this article by way of travel funds to support my visit to Kathleen's studio, but also my participation in a number of conferences and a sabbatical in the fall of 2018. Thanks, too, to the anonymous reviewers of the manuscript, whose suggestions for improvement resulted in what I consider a much stronger essay.

\footnotetext{
${ }^{73}$ Barbara Freese writes that "If coal were not so plentiful, one could imagine it lovingly displayed in museums, placed next to the (generally much younger) dinosaur bones, rather than being burned by the trainload." Freese, Coal: A Human History (Cambridge, MA: Perseus Publishing, 2003), 3-4.
} 


\section{Works Cited}

American Petroleum Institute. Pipeline 101. Published 2016. Accessed April 17, 2018. http://www.pipeline101.org/.

_. "Oil: Power Past Impossible." Video advertisement, 30 seconds. Published June 14, 2017. Accessed April 17, 2018. https://www.youtube.com/watch?v=9iw4fcPezn4.

Barad, Karen. Meeting the Universe Halfway: Quantum Physics and the Entanglement of Matter and Meaning. Durham, NC: Duke University Press, 2007.

Barrett, Ross, and Daniel Worden. Introduction to Oil Culture, xvii-xxxiii. Edited by Barrett and Worden. Minneapolis, MN: University of Minnesota Press, 2014.

Bellamy, Brent Ryan, and Jeff Diamanti. "Phantasmagorias of Energy: Toward a Critical Theory of Energy and Economy." In "Materialism and the Critique of Energy," edited by Bellamy and Diamanti. Special issue, Mediations 31, no. 2 (2018): 1-16.

Bennett, Jane. Vibrant Matter: A Political Ecology of Things. Durham, NC: Duke University Press, 2010.

Cariou, Warren, and Jon Gordon. "Petrography, The Tar Sands Paradise, and the Medium of Modernity." The Goose 14, no. 2 (2016). Accessed April 17, 2018. http://scholars.wlu.ca/cgi/viewcontent.cgi?article $=1192 \&$ context $=$ thego ose.

Dreiser, Theodore. “A Certain Oil Refinery.” In American Earth, edited by Bill McKibben, 186-91. New York: Library of America, 2008.

Evans, Mel. Artwash: Big Oil and the Arts. London: Pluto Press, 2015.

ExxonMobil. "Energy Lives Here Anthem." Video advertisement, 1 minute. Published November 27, 2013. Accessed April 17, 2018. https://www.youtube.com/watch?v=FZ3S2EOBbwE.

Freese, Barbara. Coal: A Human History. Cambridge, MA: Perseus Publishing, 2003. 
French, Elysia R. "Transformations of Oil: Visibility, Scale, and Climate in Warren Cariou's Petrography." RACAR: revue d'art canadienne/Canadian Art Review 42, no. 1 (2017): 64-72.

Gordon, Jon. Unsustainable Oil: Facts, Counterfacts and Fictions. Edmonton, AB: University of Alberta Press, 2015.

Helbig, Louis. “Alluvial Fan.” Beautiful Destruction. Accessed December 6, 2018. http://beautifuldestruction.ca/project/alluvial-fan/.

Hempton, Gordon, and John Grossman. One Square Inch of Silence: One Man's Quest to Preserve Quiet. New York: Free Press, 2009.

Hern, Matt, and Am Johal. Global Warming and the Sweetness of Life: A Tar Sands Tale. Illustrated by Joe Sacco. Cambridge, MA: The MIT Press, 2018.

Herzog, Werner, dir. Lektionen in Finsternis [Lessons of Darkness]. 1992; Paris: Canal+, 2018. Netflix video.

International Energy Agency. Key World Energy Statistics 2017. Paris: International Energy Agency, September, 2017. Accessed May 11, 2018.

https://www.iea.org/publications/freepublications/publication/KeyWorl d2017.pdf.

Johnson, Bradley. "Big Game Punting: Super Bowl Scores \$5.4 Billion in Ad Spending Over 52 Years.” AdAge, January 11, 2018. Accessed April 17, 2018. http://adage.com/article/special-report-super-bowl/super-bowl-adspending-history-charts-52-years/311881/.

Kurtz, Rick S. "Coastal Oil Pollution: Spills, Crisis, and Policy Change." Review of Policy Research 21, no. 2 (2004): 201-19.

Latour, Bruno. "Love Your Monsters: Why We Must Care for Our Technologies As We Do Our Children." The Breakthrough, no. 2 (2012). Accessed December 6, 2018. https://thebreakthrough.org/index.php/journal/past-issues/issue-2/loveyour-monsters.

LeMenager, Stephanie. Living Oil: Petroleum Culture in the American Century. New York: Oxford University Press, 2014.

Levin, Kelly, Benjamin Cashore, Steven Bernstein, and Graeme Auld. "Overcoming the Tragedy of Super Wicked Problems: Constraining Our Future Selves to Ameliorate Global Climate Change." Policy Sciences 45, no. 2 (2012): 123-52. 
Macdonald, Graeme. "Containing Oil: The Pipeline in Petroculture.” In Petrocultures: Oil, Politics, Culture, edited by Sheena Wilson, Adam Carlson, and Imre Szeman, 36-77. Montreal, QC: McGill-Queen's University Press, 2017.

Malm, Andreas. Fossil Capital: The Rise of Steam Power and the Roots of Global Warming. London: Verso, 2016.

McKibben, Bill. "Introduction.” In American Earth: Environmental Writing Since Thoreau, edited by Bill McKibben, xxi-xxxi. New York: Library of America, 2008.

_. "A Revolution in Our Atmosphere, From Burning Too Many Fossil Fuels." HuffPost, February 2, 2011. Accessed May 11, 2018. https://www.huffingtonpost.com/bill-mckibben/a-revolution-in-ouratmos_b_817860.html.

Mills, Stephanie. "Mills College Valedictory Address." In American Earth: Environmental Writing Since Thoreau, 469-72. Edited by Bill McKibben.

Mitchell, W. J. T. What Do Pictures Want?: The Lives and Loves of Images. Chicago: University of Chicago Press, 2005.

Morse, Kathryn. "There Will Be Birds: Images of Oil Disasters in the Nineteenth and Twentieth Centuries." The Journal of American History 99, no. 1 (2012): 124-34.

Morton, Timothy. Hyperobjects: Philosophy and Ecology after the End of the World. Minneapolis, MN: University of Minnesota Press, 2013.

Oxford English Dictionary. "Medium.” Oxford: Oxford University Press, 2018. Accessed April 17, 2018. http://www.oed.com/view/Entry/115772?redirectedFrom=medium\#eid.

Pendakis, Andrew. "Being and Oil: Or, How to Run a Pipeline through Heidegger." In Petrocultures: Oil, Politics, Culture, edited by Wilson, Carlson, and Szeman, 377-88.

"President Trump's State of the Union Address: Fact-Check and Analysis." Politico, January 30, 2018. Accessed April 17, 2018. https://www.politico.com/interactives/2018/trump-state-of-the-union2018-transcript-analysis/.

Pruett, Dave. "Global Warming or Climate Chaos: What's in a Name?" HuffPost, March 5, 2015. Accessed November 26, 2018. 
https://www.huffingtonpost.com/dave-pruett/global-warming-orclimate-chaos-whats-in-a-name_b_6802696.html.

Robertson, Genevieve. Language for the Wrack Zone. Accessed November 26, 2018. http://www.genevieverobertson.com/\#/language-for-the-wrackzone/.

Schuster, Joshua. "Between Manufacturing and Landscapes: Edward Burtynsky and the Photography of Ecology." Photography and Culture 6, no. 2 (2013): 193-212.

Stoekl, Allan. "Unconventional Oil and the Gift of the Undulating Peak." Imaginations 3, no. 2 (2012): 35-45. Accessed April 17, 2018. http://imaginations.glendon.yorku.ca/?p=3640.

Swanson, Heather, Anna Tsing, Nils Bubandt, and Elaine Gan. "Bodies Tumbled into Bodies." Introduction to Arts of Living on a Damaged Planet: Ghosts and Monsters of the Anthropocene, M1-M12. Edited by Tsing, Swanson, Gan, and Bubandt. Minneapolis: University of Minnesota Press, 2017.

Szeman, Imre. "The Cultural Politics of Oil: On Lessons of Darkness and Black Sea Files." Polygraph, no. 22 (2010): 33-45.

Thoreau, Henry David. Walden; or, Life in the Woods. 1854. Reprinted with introduction and notes by Bill McKibben. Boston: Beacon Press, 2017.

Thum, Kathleen. Portfolio: 2017 to 2013. Accessed April 17, 2018. https://kathleenthum.com/section/462562-2017-to-2013.html.

Timofeeva, Oxana. "Afterword." In "Materialism and the Critique of Energy," edited by Brent Ryan Bellamy and Jeff Diamanti. Special issue, Mediations 31, no. 2 (2018): 145-48.

United States Environmental Protection Agency. "Basic Information about Visibility.” EPA.gov. Last modified April 25, 2017. Accessed April 17, 2018. https:/www.epa.gov/visibility/basic-information-about-visibility.

Welling, Bart H. "Petronarratology: A Bioregional Approach to Oil Stories." In "Ecocriticism and Narrative Theory," edited by Erin James and Eric Morel. Special issue, English Studies 99, no. 4 (2018): 442-57. Accessed December 5, 2018. https://www.tandfonline.com/doi/full/10.1080/0013838X.2018.1488097.

Zuromskis, Catherine. "Petroaesthetics and Landscape Photography: New Topographics, Edward Burtynsky, and the Culture of Peak Oil." In Oil Culture, edited by Barrett and Worden, 289-308. 